\title{
日本機械学会論文集 揭載予定目次
}

\author{
A 編（材料力学・材料など）

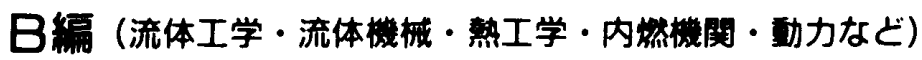

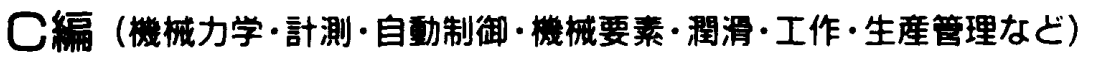

\section{第62巻 595 号}

\section{$1996 \cdot 3 \cdot 25$ 発行}

\section{$\mathrm{A}$ 編}

(論文)

オーステンパ球状黒沿鋳鉄の高サイクル披労に及ぼす表面硬さの影響

ステンレス鋳鋼の回転曲げ及び权じり疲労挙動の比較

土居滋, 原田昭治, 高原正雄, 廣安 武, 池田秀男

·田中括志，西谷弘信，滕崎涉，寺西高広，田中泰彦

$\mathrm{Cr} \cdot \mathrm{Mo}^{-} \mathrm{V}$ 鍛鋼の疲労損傷発生に対する統計的解析

..生野 健, 後藤徹, 田中健 …, 植松幹雄, 隅田武男, 小西隆 試験片断面形状が異なる場合におおる平面曲げ披労強度の評価（微小き裂伝ぱ則による検討）

..皮籠不了紀雄, 西谷弘信, 王 習術, 井手英夫, 田中秀穂 常圧焼結窒化けい素セラミックスの高温引張圧縮繰返し披労強度に及ぼす心波形効果

幡中憲治, 勝山将司, 高木英樹

同一強度水準の ADI の波労信頼性に及济す凝固時の冷却速度の影響

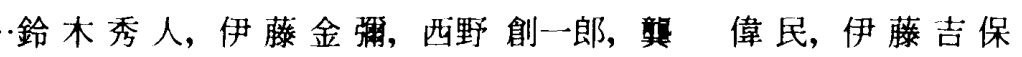

急冷凝固 ADI の波労信頼性向上に抢ける最適 SP 条件の検討

..鈴木秀人，伊藤金雨，西野創一郎，山田壮一，森谷光孝

材料強度信頼性データベース（MSDRD）による機械構造用鋼の確率披労特性に関する統計解析

.西川出, 岡田惠司, 酒井達雄, 後藤真宏, 西島敏

牛緻密骨の波労過程のき裂発生進展特性と波労過程のコンピュータシミュレーション

残留応力を有するクラッド材に扔ける半棈円表面き裂の波労伝ば挙動の推定

石原外美，尤嶋孝保，東川弥，永森治

…过昌宏, 大路清鸸, 久保司郎, 井関康人, 蒲昭

疲労を受けた純銅の粒界き裂発生と転位組織………………兼城英夫, 片桐一宗, 真壁朝敏, 系村昌祐 大き裂における微小き裂伝ぱ則の有効性 ……波籠石 紀雄, 西谷弘信, 豊. 廣利 信, 王 習術, 田中秀穂 モード III 非定常高速伝ぱき裂先端漸近解の数式処理による導出……………………西岡俊久, 近藤慶治 時効硬化 $\mathrm{Al}$ 合金 6061-T 6 の微小き裂伝ぱ速度の統計的検討

後滕真宏, 皮籠石 紀雄, 西谷弘信, 三浦篤義

き裂を有する不静定はりの塑性崩壞挙動と終局強度………劉 松 柏, 甘高章隆, 小島 隆, 安藤 柱 ポアテイル法によるアルミナセラミックスの新しい破酒解析方法…………………上野 明, 高 行男

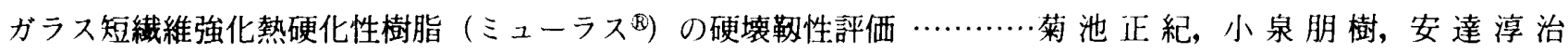
赤外線放射加熱による熱衝撃破壊勒性試験………………………………………………....淡 路 英 夫 化学装置で用いられたタンタル製部材の水素ぜい化の非破壊的評価と寿命管理………中. 原 正 大, 庄子哲 雄 境界要素法による直交異方性体の二次元定常熱弾性解析（第 2 報）………………石 黒 周 司，田中正隆 境界領域要素法による組立板構造の強制定常振動解析…………………田中 正 隆, 松 本敏 郎, 塩 䗁 明 不均質平板の非定常熱応力の三次元解析…………………菅野良弘, 佐藤恵一, 木村範貴, 須 見 尚 文 部分加熱による板材の二次元熱弾塑性曲げ変形解析………谷川義 信, 石原 正 行, 森下博之, 河村隆介 超弾性体の混合型有限要素解析に関する基礎的検討………………………………渡辺浩志，久田俊明 金属積層板の引張曲げ・曲げ戻しにおける变形挙動………………..野 隆太郎, 岡田達夫, 吉田総仁 
特異積分方程式法による円孔を有する弾性体における接触問題の数值解析 テーパーラップ継手とスカーフ継手の衝撃変形に及ぼす重权合せ接着接合部形状の影響

藤木浩司，三浦博之 岩田英生，佐滕千明，池１：皓三

超音波探傷によるスポット溶接継手の機能評価に関する研究（第 1 報, ニューラルネットワークによる

引張せん断強さの非破壊評価) ……………………………宅間 正則，新 家 舁，元野 等 ポリプロピレンの変形特性に及ぽすひずみ速度及び温度の影響…………有山 堯，森 保成，金子堅司 フィレット部を有する段付丸棒及び段付平板の忘力集中についての考察……………....野田尚 昭，高 瀬 康 粘弾性砈力棒を用いた Split Hopkinson Bar 法…………曾我部 雄次, 横 山哲也, 中野元博, 岸田敬三 線維芽細胞が発現する引張応力と自己組織化（培養系における実験的検討）…………高久田和夫，宮入裕夫 固有ひずみ法による配管及び平板の溶接突合せ継手の残留応力の検討

望月正人，斉藤直人，坂田信二，魚住弘人

非共軸モデルによるひずみの局所化解析に抢けるスピンの影響….... 黒田充紀

金属材料の粘塑性特性とひずみ時効に及ほす予加工と変形速度の影響（第 3 報, SCM 435 調質銅に対する

単軸応力下での応力制御負荷及びクリープに対する検討） 小山田隆信，金子堅司 超塑性材料の圧縮試験に抢けるひずみ速度感受性指数 $\mathrm{m}$ 值の評価

吉澤宗晴, 村上直也, 山内徹, 大澤泰明 単純支持された対称積層板の座屈荷重に対する感度解析…………………小曾 㕵, 郡 暁 文, 室律義 定 逆問題解法による光 CT のシミュレーション ………………....Matthew R. JONES, 山田幸生，手塚 明 分子動力学法による単元系アモルファス金属の微視的空間構造と内部応力の評価

$\mathrm{Al}$ 粒界近傍のストレスマイグレーションの分子動力学解析

中谷敬子，北川浩，中谷彰宏 北川浩, 中谷彰宏, 尾方成信, 斎藤賢一, 前川幸弘 複合材料のマイクロ構造における幾何学的非線形性と破壊を考慮した均質化解析手法

高野直樹，座古 勝，平郡久司，菊池舁

$\mathrm{AE}$ を用いた TiN 薄膜の付着力評価方法の検討 尾田雅文, 原利昭 半導体チップのワイヤボンディングプロセスに扔ける損傷評価解析

池田徹, 工藤清輝, 宮崎則幸, 宗像 健, 有田潔, 焼山英幸 せん断流動下での炭素瀻維分散シリコンオイルの導電性挙動（二重円筒型電極の場合）

船橋正弘，北野武 均質化法による織物複合材料の三次元マイクロ構造設計（第 2 報，曲げ負荷時のマイクロスコピックな挙動 の詳紐解析) 高野直樹, 座古

勝, 坂田 誠一郎

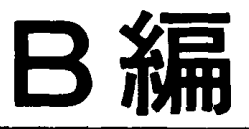

(論文)

渦放出の完全ロックイン領域における不規則特性（渦形成長さの変動特性）

\section{会員特価：4600円 \\ 定 価：5150円（本体 5000 円） 送 料：100円}

高比速度遠心ポンプに生じる激しい壊食の壊食率の推定法

羽二生博之, 坂本弘志, 田中大介, 小畑芳弘 ..祖山均, 季 受人, 外崎昌志, 浦西和夫, 加藤 洋 治, 大場 利三郎 壁面パルスジェット内に生成された縦渦の流動機構（第 1 報, 単純パルスジェットの吹き出し条件）

鈴木孝之, 長田光彦, 志沢高朗, 本阿弥䢐治 壁面パルスジェット内に生成された縦渦の流動機構（第 2 報, 複孔パルスジェットの干涉）

鈴木孝之, 長田光彦, 志沢高朗, 本阿弥畺治 超音速内部流路におけるキャビティまわりの流れ特性………坂本和之, 藤井孝藏, 田村善昭, 松永康二 二原子分子衝突モデルの構築（第 1 報, 分子衝突の分子動力学シミュレーション)……松本 洋一郎, 徳 增 崇 
二原子分子衝突モデルの構築（第2 報，モデルの構築とその検証）…… .徳 增 崇, 松本 洋一郎 分子動力学法による気体分子一固体表面間相互作用の解析（第 1 報, $\mathrm{O}_{2} /$ Graphite 系のシミュレーション)

松本 洋一郎, 小西伸宏

$\mathrm{O}_{2}$-LIPEにおける|四転スペクトルシミュレーション 平井悦 郎, G. Gundlach 沸騰二相流における管群の振動心答特性（第1 報, $2 \times 2$ 管群でひ)管の拢動举動）

宦野 廣, 斎藤

登, 尾崎 脩, 星出明彦

磁性流体沸騰二相流の安定性に関する研究 淳, 大久保 雅章, 神山新一 垂直円管内の沸騰を伴う流動の叮視化実験（小質量速度，小加熱熱流束の場合）

..水野知博, 新井隆景, 杉山弘, 内山尚 プローブとして中性子を用いた金舅管内気液二相流の可視化と計測（第3 報，中性子ラジオグラフィ画像の 足量化法) 日月倰, 三島嘉一郎 合流分岥部を通る流動形態と壁せん断㤁力……山口隆平, 岡部 洋, 野川順一, 氏家弘, 高倉公朋

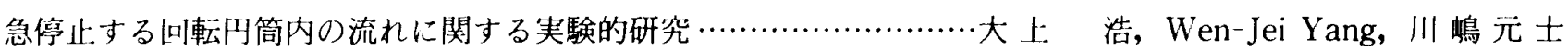
振動壁を有する二次元チャネル内脈動流の地力損失…… .中村 雅 英, 有働 嘉 郎 アブレシブジェット加エ面に生じる縞状粗さに関する実験的解析

福酒, 津田直明, 阿部 明 高速水中水噴流の流動構造と揁稘特性に及ぼすボリマー添加の影響

清水誠二, 釜井崇成, 谷岡邦宏, 村井等 定常及び脈動自由墳流の) 4 解限分類による測定 井口学, 山田栄二, 植村知 正, 山本富士夫 スロート近傍における境界㕌のパッシブコントロールが遭音速ディフューザに及ぼす影響

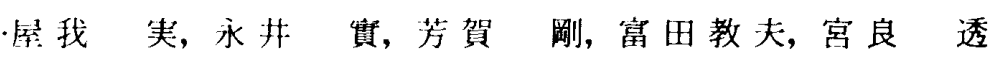

不足膨張衝突噴流の唗動現象 神原洋子, 岩本 順二郎 有限要素法による非比綰性二流体モデルの数值解析（数値解法と円柱まわりの流れ解析）

内山知実, 峯村吉泰

機械的人工弁の流れ場の解析 (Starr Edwards, Bjork Shiley c-c, 及び St, Jude 弁の比較)

阿久津 敏乃介, Winona F. BISHOP, Vinod J. MODI 数値解析による流体音の音源分布の解析…………………古池 治孝, 石原国彦, 後藤知伸, 高野泰斉 乱流の繰込み理論に関する研究（第 1 報, 乱流モデル構築に関するYakhot Orszag-Smith 理論の評価)

.長野靖尚, 板津義博 だ円断面管路|内助走区間発達乱流構造の実験解析…………杉山 均, 秋山光庸, 若山英樹, 渡辺岳男 低レイノルズ数型 $\boldsymbol{\kappa}^{-} \boldsymbol{\epsilon}$ モデルによる吹出しのあるチャネル乱流の数值計算 佐野正利 離散化ナブラ演算子法によるNavier Stokes 方程式の解法とP(oisson 方程式の高速解法

混合要素法と離散化ナブラ演算子 池江＼cjkstart浩，棚橋隆彦，水上誠二，金山美紀子 オブジェクト指向 FEM のための離散化ナブラ演算子 棚 橋隆 彦, 中井太二郎, 山本貴 史 超音速軸流速度ファンの流㧈解析 棚 橋 隆 彦, 中井 太二郎 收束性を考慮した動的負荷分散手法によるオイラーう程式の並列計算……小幡让規, 鉿木智博, 里深信行 列車まわりの流机の数値シミュレーション (第 2 報, 後尾車屾に加わる非定常空気力)

.鈴木昌弘, 新井紀夫, 前田達夫 二重反転式軸流送風機の乱流騷督の尒測 览五好雄, 林 秀千人, 三村 雄次郎, 深野 徹 ボンドグラフによるトルクコンバータの動特性解析……………………鈴 木勝也，中村育雄，田中和博 非定常加熱時の低熱流速膜沸騰遷移に関する研究（第2 報, 伝熱面材料, 性状の気泡挙動に与える影響） 奥山邦人, 飯田嘉宏, 加藤尚 光線放射モデルによるふく射要索法 $\left(\mathrm{REM}^{2}\right)$ を用いた任意形状ふく射性媒体と物体面間のふく射伝熱

壁面墳流による平板上の熱伝達制御・ 島田厂八, 橋本

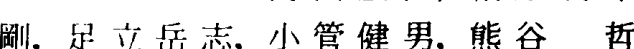


後ろ向きステップ流れ場の受動的・能動的伝熱促進の熱的性能評価

·親川兼勇, 照屋 功, 瀬名波 出, 屋我 丰, 焦㴊幾夫

鈍頭平板まわりのはく離と再付着を伴う流れおよび熱伝達の三次元数值解析… 柳岡英樹，太王照和 炭酸ガスの体積力対流凝縮熱伝達(凝縮状態と熱伝達の関係)…………石原＼cjkstart熏，松本亮介，海老原 努 多孔質体内の非ニュートン流体の熱流動(第 1 報, 流動の二次元数値モデル)…………井上昌彦, 中山 顯 マッハ・ツェンダ画像による非定常二次元温度場の奏験解析

筒井憲博, 秋山光庸，杉山均，高藤圭一郎 レーザパルスを受ける有限媒質ゆの非フーリエ温度波伝搬………….................唐 大偉, 荒木信幸 電場における気泡成長の数値解析…………高田保之, 白川英観, 田中克典, 黑木虎人, 伊藤猛宏 放熱フィン一体型プラスチック LSI パッケージの熱設計 …………....米田奈柄, 北野誠, 清水一男 対向二相流下水制限に及ほすす注入水サブクーリング効果に関する研究…… ..数土幸夫 LSI パッケージ塔載用ピンフィン型ヒートシンクの噴流冷却における熱抵抗の簡易予測法

近藤義広，松島均

ヒートパイプを用いた大電力半導体冷却システムの熱腹歴解析

鈴木 敦, 藤岡和正, 桑原平吉, 高崎利夫 流水中に置かれたフィン付冷却平板上の凍結促進…….....................平打哲夫，不川正昭，北川一栄

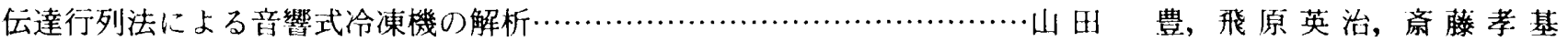
-・重効用吸収冷凍機の吸収サイクルの構成法がその特性に与える影響の検討

斉藤潔, 无十嵐 洋晃, 河合素直 $3.39 \mu \mathrm{m}$ 赤外吸収法による岑化水素燃料濃度の計測 ………吉山定見, 浜本嘉戟, 富出栄二, 南 健一 分岐型燃焼器に関する研究（火炎形状と火炎安定性）……………......野寺英輝，藤百尚毅，辻正一 二次元混合凰内に形成された火炎の成長に関する数值シミュレーション（第 3 報，渦によって誘起される



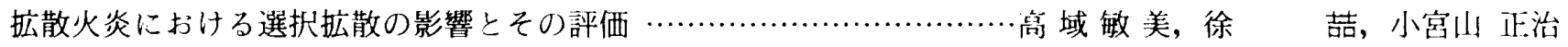

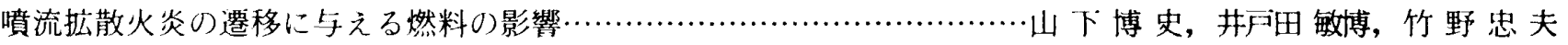
上流旋回式インジェクタの噴霧特性に関する研究（第 4 報，エアアシスト噴霧の微粒化特性）

阙本良雄, 天羽清, 岸敦夫, 内村隆俊

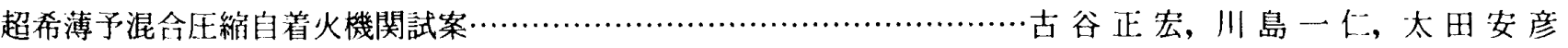
セミフリービストンスターリングエンジン再生器の複合メッシュマトリックスによる性能向上

浜门和洋, 野川正文, 百頼豊 壁面に浻って成長するディーゼル噴霧の挙動………………………江原拓末，天谷賢巟，新井雅隆 レーザドップラー法によるディーゼル機関用央状噴霧流の特性解析（第２報，LDA 法による速度分布の解析）

·隆武強, 石間経章, 小保方富夫 六ストロークディーゼル機関の性能予測（第2報，予測棓算と急速厓縮膨張装置を用いたモデル実験）

天谷賢览，張

峰, 新井雅隆

ディーゼルエンジンの排気 PM 濃度と潤滑油性能低卜に関する研究

吉川英夫, 安道俊次, 松井愃, 武田信之

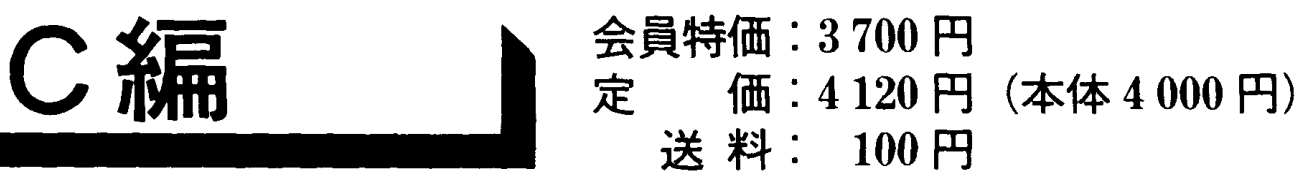

(研究展望)

グローバル情報化生産システムに向けた知能化工場の構築

長尾高明，畑村洋太郎，光不衛，中星政之

(論文)

積層偏平・シェルの振動特性の最適化 成田吉弘, 趙 希禄 
反共振強化形アクティブ制振装䈯の開発

安田正志, 顧栄篓, 西原修, 松久 寛, 樢 飼 邦夫, 近藤

実

遺伝的アルゴリズムによる受動形ジャイロ制振機構の最適設計（不規則励振におけるモンテカルロ最適化）

..西原 修, 石原 広, 松久 寛, 佐藤 進

VSS 理論による振動絶緑及び制振の研究（第 2 報, 多自由度振動系) ……川口秀谷, 小田益男, 塩谷駿介 構造物の振動制御のためのシーソ形アクティブ動吸振器 福井宏治，吉田和夫，大久保毅

$\mu$ 一設計理論を用いた SCARA 型ロボットの防振制御

石黑照敏, 大嶋和彦, 康子博, 早川義一, 藤井省三 歯車減速機構の内部励振に基づく回転速度変動の自己補償制御による抑制（第 1 報，ハーモニックドライブ

減速機の強制励振成分の低隇)

·伊藤昌彦, 賀勢晋司, 媣田茂生

フィードフォワード型電圧制御による密閉形玨縮機の振動低減（第 1 報，シミュレーションによる制御効果

の基礎検討）……………………过内伸好，小泉孝之，稲田征治，富沢 让雄，丁野篤 支持部にがた・摩擦を有するプラント配管系の地震応答……渡遑鉄也，鈴木浩平，三森友彦，清水信行 摇動を利用した推進機構. 佐藤勇一, 高峰

鉄道車両のアクティブサスペンションにおける油圧アクチュエータの適用性（実物大車両模型による

試験台実験) 谷藤克也, 島宗亮平

ニューラルネットワークシステムを用いたタイヤのモデリング……………………曹 喜 永, 景山一郎 スキーヤーとスキー板の連成運動（「立ち「卡り゙加重」動作及び「沈み込み抜重」動作の解析）

高粘性流体封入マウントの動特性に関する研究（周波数依存性，振幅依存性のモデリングの検討）

坂田敏行, 包子邦光 .浜崎義弘，米澤智志，井上喜雄 未知パラメー夕をもつサーボ系に扔ける動的トルクのロバスト $H^{\infty}$ 推定器の設計 ……朝 倉 倰 行, 劉 平 積層型压電素子で駆動されないソフトハンドリング・グリッパ（第 1 報, 解析モデル並びに微小把持力制御)

江 鐘偉, 長南征二, 佐藤 正行

磁気へッド接触計測用薄膜厌電 $\mathrm{AE}$ センサの出力特性に関する検討

今井郷 充, G.J. Burger, T.S.J. Lammerink, J.H.J. Fluitman ニューラルネットワークによる導管網漏洩位置推定 ..竹内淳, 小杉幸夫 ロボットを用いた探り動作による対象物と環境の接触位置情報の推定……吉川恒夫，余永，小池雅司 音響信号を利用した液面レベルと傾斜角度の測定…………島島 崎 義之，…宮亮…, 坂本秀一, 田中誠三

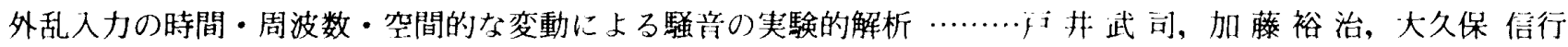
速度センサ併用高温超電導ハイブリッド磁気浮上采の $H^{\infty}$ 制御

金澤䫓襀，松田健一，岡由養 - , 谷 順二 ゼロパワー磁気軸受系の離散時間スライディングモード制御…………....野波健 蔵，信科研 - . 斉藤 満 電気自動車の運動制御に関する研究…… ..那須秀俊, 桶笠博正, 芳村敏夫 自由関節を有する 2 リンクアームの摩摖を利用した位置制御……………志藤 嘉 信, 柳 基 鎬，猪 岡 光 宇宙マニプレータのロロバスト制御

丹羽昌平，井上淔丈，城之内博之，鈴朴正之, 安藤嘉則，三井浩一 ファジィ・ニューロを利用した複腕ロボットによる摩摖補償を考慮した対象物の滑らせ移動制御

本口量夫, 福田敏男

確率ファジィ制御（第 1 報，理論導出） 渡辺桂吾

確率ファジィ制御（第 2 報，先験確率とファジィ集合拉よび制御ルールの関係） 渡辺桂吾 確率ファジィ制御（第 3 報, 移動ロボット車の軌道追従制御への応用） ..渡辺桂吾, 野見山 章 円錐継手の油圧による取り外しの研究 ..牧博司，菊池正紀，坂田竜也 ステアケース法を用いた転がり軸受の寿命試験………市川茂樹, JUHARTONO, 小奈 弘, 吉本 勇 多孔質ジャーナル軸受の潤滑機構に関する研究（流体潤滑状態下における油膜压尔布について）

金子覚, 村上宏, 井洋喜 
転がりすべり接触におけるアルミナセラミックスの摩耗機構（摩耗過程に及ぼすトライボフィルムの影響）

足立幸志，加藤康司

$\mathrm{SiC}$ ウィスカ強化樹脂の摩耗特性とその応用 ……洞口＼cjkstart䈆，J.E.D. Afaghani，山口勝美，中本 剛 潤滑膜の多孔質性を考慮した希薄気体修正レイノルズ方程式の導入………矢保永, 鄧 志生, 大岡昌博 歯車強度設計への境界積分方程式法の応用（第 3 報, 角点処理と解析精度の向上について）

䨑車強度設計への境界積分方程式法の忍用（第 4 報, 無限領域問題及び内歯車問題への拡張）

中道彦, 藤井寛 - - , 安西理央 ·藤井寛二, 安西理央, 田中道彦

エリコン式まがりばかさ畨車の䨑のたおみについて

青山栄一, 廣垣俊樹, 上西康弘, 新井典久, 橋元幸治 CNC 歯車測定機による円すい形インボリュート歯車の歯面测定法………留謙一, 後藤徹, 上田武司 はすば雪付べルトの騒音に関する研究（ねじれ角の影響）……….........小山富夫，上田博之，籠谷正則 はすば歯車の三次元的雬面修整に関する研究（霜車軸の曲げによる軸角と歯当たりの変化）

浸炭焼入れした歯車の面压強度の向上に関する研究（ショットピーニングとバレル処理の効果）

穗屋下 茂, 橋本宗到, 加茂秀敏, 松野下智博

歯付きベルトの振動特性に関する研究（移動負荷を受ける場合）………李 紹昌，大滝英征，綿貫啓一 八イポイドギヤの端部㐘当たりに関する研究（第 1 報, 理論解析）……伊滕紀男, 高橋幸一, 西尾淳也 ハイポイドギヤの端部歯当たりに関する研究（第 2 報，端部茵当たりの特珙性）

超多機能T.作機械の設計と評価に関する研究（要求仕様分析と設計）

伊藤紀男，高橋幸一，酒星淳也

杉村延広，上野滋，三島望，八賀聡一

超大型軸材の鍛造に㧈ける内部空腙压着に関する研究（第3 報，表面冷却鍛鍊法の改善による空隙圧着条件

の達成）……………………………小野信节, 南克之, 村井悦夫, 岩舘忠雄

円筒絞り成形におけるボディしわについて……........................後滕学，林哲録，荒浪勝

加丁能率の異なる並列機械スケジューリング……………柳川佳也，宫崎茂次，平方敏，寺䚾信幸 ダイレクトコントロールカ式による形状適応切削システム

原由宏幸，鍵和田忠男，佐々木 雅之，笠原 慎 超微細結鼠構造を有する多結晶型 CBN 砥粒の研削特性…市田良夫, 貴志哔三, 鈴木正治, 二階堂知已 セラミックス压粉体の焼結における割れ発生の预測 ………………....森謙 - . 郎, 宮崎雅英, 小坂田宏造 運動成分拘束を考慮した架間機構形成の総含

坂本吉弘, 小川潔, 萩原芳彦, 堀江三喜男, 有島隆行 視覚センサ塔載の自律移動ロボットによる丁字パイプ継手の溶接線認識と自動追従

菅泰雄, 斉滕圭伸, 佐野武司, 石井秀明

シールド掘進機用スクリュコンベヤ内土砂の压力降下

吉川忠男

同一距離関係をもつ配置場所をグループ化したレイアウト解法…………永木二郎, 柳川佳也, 宮崎茂次 多次元空間ベクトルによるマシニングセンタの市場競争力評価…………李厚祥, 新野秀憲, 伊東誼 一方向走行レーンをもつFMS 工場における複数 AGV の運行スケジューリング（遺伝アルゴリズムによる

調和スケジューリング)……...................古川正志, 渡辺美知子, 玉山裕也, 嘉数侑昇 結合優先関係グラフに基づく製品の組立順序の生成（第 1 報，結合優先関係グラフの定義とその操作方法）

王堅，大倉和博，上田完次 自動フィクスチュアリング設計システムの開発 ……....................池 添尘琴, 青山藤詞郎, 渡部 和 生物指向型生産システムに打ける簡単なモデルを使った生産スケジューリング問題の一解法

大倉和博, 上田完次 